\title{
STRATEGIC ADAPTATION OF TOURIST DESTINATION PRODUCTS TO CONTEMPORARY TOURISM TRENDS: A CASE STUDY OF FRUSKA GORA NATIONAL PARK
}

DOI: http://dx.doi.org/10.18509/GBP.2020.65

UDC: 338.487:339.113.2]:005.52:005.33(497.11-751.2)

\author{
Svetlana Vukosav \\ Vuk Garača \\ Milan Bradić \\ Jelena Tepavčević \\ University of Novi Sad, Faculty of Sciences, \\ Tourism and Hotel Management, Serbia
}

\begin{abstract}
In order to maximize tourism development in the Fruška Gora National Park, it is necessary to define for those activities that enable the formation of a tourism product that can be marketed on the tourist market. The formation and design of a tourist product depends on the type of tourist destination, and the development of new trends in tourism imposes a constant need for modification, new design and creation of new attractiveness when forming a tourist product. In modern business conditions and trends in the tourist market, it is imperative to work on improving the management of tourist areas with the aim of preserving it and improving the quality of development of these areas. In order to create the best position of the tourist destination in the tourist market, as well as to create a differentiated advantage over the competition of the modern tourist destination, their strategy is constantly adjusting to more sophisticated demand, and the strategy itself begins and ends with selected market segments. The implementation of a combination of adequate strategic alternatives in Fruska Gora National Park in the present turbulent environment is an effective way of managing in order to create strategic harmony between the resources of the destination and the threats and opportunities that operate from the environment. Therefore, the aim of this paper is to point out the necessity of strategic adaptation of Fruska Gora National Park as a tourist destination, to market trends and to find the optimal strategic mix in order to ensure the efficiency and effectiveness of the Fruška Gora National Park as a competitive tourist destination.
\end{abstract}

Keywords: strategic adaptation, tourist destination, tourist products, contemporary tourism trends, Fruska gora National park

\section{INTRODUCTION}

The expansive, uncontrollable growth and the development of tourism during the previous past decades are followed by numerous ecological, social and cultural consequences. That is why there is a need for the concept of sustainable development in this area, which in essence directs on the necessity of strategic thinking about the future development of touristic spaces and regions [1]. Especially, it is necessary to apply this concept to the oldest natural goods and touristic resources and those are the national parks. Sustainability of tourism development within the national parks depends on the ability of the environment to secure the stable and long-term development base of these resources [2]. All the participants and the carriers of touristic activity have a task to adapt to this 
new development strategy and the way of thinking. Besides, the success of the touristic destination will more and more depend on its sensitiveness compared to the intensity of flows in the surrounding. Meeting the business goals of the touristic destination depends on its ability to satisfy the needs and wishes of the consumers (tourists) and with the adequate combination of the instruments of market access or finding its optimal combination through the choice of strategic alternatives. Defining and choosing the strategies is a very complicated process, especially because with the appearance of numerous destinations comes a great number of touristic products and a greater chance of the market segmentation on smaller homogeneous groups of consumers. That is why when creating the strategy for directing the touristic destination there is a question of what type of product we should create, where we can place it and how to position ourselves on the chosen market. That is why when creating the strategy for directing the touristic destination as well-positioned touristic destination its strategy is constantly adapted according to the tourist demands and the strategy itself starts and ends with the chosen market segments. The National park "Fruska Gora" is the oldest national park in Serbia, founded in 1960. The name of National park Fruska Gora came from the mountain with the same name and the name Fruska Gora came through its adjectival form "ethnic Frug" with the meaning "Roman" and in that way, the name of this mountain keeps the memory of one ethnical community that disappeared from this territory a long time ago [3].

The application of strategic directing concept in the National park "Fruska Gora" in today's turbulent conditions represents the efficient way of directing to create strategic harmony between the resources of the destination and threats and opportunities from its surroundings. So, the aim of this paper is to point out the necessity of strategic directing in the National park "Fruska Gora" and finding the adequate strategy for securing the efficiency and the effectiveness of the National park "Fruska Gora" activities as a touristic destination and promotion of its growth and development.

\section{METHODS}

Primary data for this research is gathered through fieldwork that relied on a direct conversation - the interview with the management of public company "National park Fruska Gora" that is managing this natural good. This interview consisted of 32 questions related to the management and marketing of touristic destination, where 9 questions were related to the process of strategic management. The interview was done in May, 2019. During the research process, several other methods were used: the research of primary and secondary data, the analytic and synthetic methods, critical and descriptive methods. The analysis of the secondary data represents the basis of this research and this paper [4] and included the analysis of domestic and foreign literature from this area and the systematisation of data gathered from the management of accommodation facilities from the National park.

\section{THE PROCESS OF STRATEGIC MANAGEMENT AND TRENDS ON THE TOURISTIC MARKET}

The tourism industry depends on external factors more than other businesses and industries. Specific attention should be given to external factors that can influence the competitive advantage of firms and destination [5], [6]. Natural resources, in particular, can be considered critical factors of success in this industry. The strategic directing of touristic destination denotes the choice of adequate path through which the touristic 
destination should in long-terms ensure the competitive position in the touristic market as well as the plan of action based on the anticipated conditions in the surrounding. Everything is done to adjust to the market conditions and the trends to meet the defined development goals [7]. The successful strategic directing of the touristic destination must have these characteristics:

- The strategy must focus on the completeness of touristic destination's activity,

- The strategy must ensure successful and durable adjustment of touristic

- destination's activity with its surroundings. There is a certain danger if management first develops missions, goals and guides of touristic destination and only after that considers the significance and influence of surrounding,

- The strategy must be oriented to question of internal limits (especially on issues

- and inelasticity of the offer),

- The strategic directing must be oriented to make long-term decisions that are

- important for the growth and development of the destination [7].

So, strategic management is observed as a continuous, interactive process which consists of several phases [8]:

- The analysis of surrounding,

- Directing the organisation (mission and goals),

- Strategy formulation,

- Strategy implementation,

- Strategic control.

The touristic destinations that want to survive and succeed in the tourism market must know everything about the new trends in tourism and include them in their strategy because yesterday's

touristic needs and demands are old. The rapidity of change and following the trends brings the need for questioning and changing the strategy and the plans to compete with the market demands [9]. In this way, the organisation of resources and work is changed. Following the modern touristic trends on the touristic market, there was noticed a great call of touristic demand for health-recreational, winter-sports activities and contact with the unpolluted environment (which especially reflects on critical review of the place and the position of tourism as the factor of saving and degradation of space) [10]. On the wave of so-called "green paradigm" that denotes the transition of specially developed countries from the western hemisphere regarding the ecotourism and its sustainable growth and awareness about the necessity of change in behaviour, there are more and more words in the touristic literature about so-called "green destinations". This means that in future tourism development, those places and areas with the preserved environment will be the most popular ones and after them those areas that include in ecology the preservation of cultural-historical attractions, anthropogenic and other factors important for the touristic development [11].

Hoteliers and touristic agencies, as well as touristic destinations, will have to take care of the number of factors which in basis bring the change in the behaviour of the tourist demand [12].

- The permanent improvement of natural attractive factor is expected,

- The permanent improvement of computer technology in tourism is expected,

- "Sun, sea and sand" will still be very popular,

- Today's touristic "heaven" (on many destinations like Hawaii, Seychelles,

- Comoros) will be future standard,

- The trip will be a kind of adventure (to see, to hear, to find out), 
- The exotic will be popular (unknown, unique),

- Culture and education will be more and more popular as a part of touristic packages etc.

In this context, certain trends will appear like for example:

- The trend toward the trip to destinations with a preserved natural environment,

- The trend of increasing the presence of adventure on the touristic trip,

- The trend toward greater involvement of individual tourists (they travel alone

- and search for a product made according to their needs),

- The trend toward a greater presence of wellness content,

- The trend of traveling to sunny destinations,

- The trend toward cheaper accommodation,

- The trend toward shorter and more often trips,

- The trend toward spontaneous deciding about the trip,

- The trend toward the often change of destinations (the trip is attraction "per se" and it is traveled to more than one destination).

\section{DEFINING THE MISSION}

The mission or the purpose represents the basic function or task of the hospitality-touristic company that differs it from other companies and especially from the competition. It should illustrate the main reasons for company's existence [12]. The missions define goals in space and time. Properly defined mission directs the decisions about the strategic vision and strategies and represents the base for implementation of its goals and other plans according to the hierarchy. It expresses the ethical principles of business behaviour that will be implemented in the company's business [13]. Properly defined mission directs the strategic thinking and deciding, gives limits or framework of the company's business and contributes to the coordination of the complete company's activity in space and time. Based on what we have determined through field fork, in conversation with the management of public company "National park Fruska Gora" we can formulate the mission for this touristic destination.

The mission: Giving the unforgettable destination experience to the tourist by putting their pleasure and sustainability in the first place with active participation in protecting the environment and the development of touristic destination.

\section{Goals}

From the aspect of planning, the goals represent a set of plans of a higher hierarchical level that come from the mission and the vision [12]. So, the company's goals represent the elaboration of a previously determined mission to regulate the process of directing. In that case, these goals are determined for "National park Fruska Gora"

- Adjust equipping, arranging and space usage with the principles of the sustainable development that include meeting the needs of protecting, taking care and improving the space and securing the conditions that staying in this area represents a unique experience

- Chose those forms of tourism, or that kind of touristic product that is competitive on the touristic market - considered specific (relied on the primary attractiveness of this area) or scarce on the touristic market and on those that least endanger the environment 
- Conceive the development of tourism so that it flows constantly in time and space and choose those forms of tourism which organisation can start immediately and without big financial investments

- Establishing the touristic agency owned by the National park with the function of bringing and organising stayings on Fruska Gora and in the National park

It is necessary to create a touristic image of Fruska Gora or representative product on the touristic market. The base for this should be linden, vineyards, monasteries, poets, trips. That should be the subject of elaboration through concrete marketing development programs.

During the first stage of touristic activation of the National park different types of excursion tourism should be developed; those types that do not need big investments in material goods, but ask for good organisation and complete marketing. However, with the fact that the excursion touristic movements usually bring small profit or no profit at all, it is necessary to start the restoration of the material base or the touristic object for accepting stationed guests, because stationary tourism brings profit.

Also, the National park must prove the right of directing over its resources and the right to use them as well as to meet a certain level of disposal over its objects. As it was mentioned it is necessary to establish the touristic agency within the National park that would have a receptive role or take care of accommodation, acceptance and organising the stay in Fruska Gora as well as to have a task to get in touch and sell touristic products through mediators, other touristic agencies in its close and further surrounding. In this way, safer sources of income are established based on selling the services in objects.

The research of the tourist market is the necessary component of all the marketing activities and represents the condition for successful business in modern tourism. In the absence of previous researches, it is necessary to start these activities immediately.

The space arrangements of locations must be adjusted with the existing network of objects, resources lay-out so that those sites are on easily accessible locations in the emissive zones of surrounding cities. The visitor should be informed about them, so it is necessary to open another informative centre.

\section{SWOT analysis as a precondition for a successful choice of the strategy}

Every touristic destination examines its situation and competitive position and formulates the strategy in dependence from planning future events. The basic problem is how to choose a suitable strategic alternative or what relevant pieces of information and predictions we use to choose the strategy. For that we can use the SWOT analysis as the result of the internal and external analysis of the environment, considering internal or external orientation on growth to minimise the weaknesses and maximize the strengths [12]. The SWOT analysis is widely used both in strategic planning and in marketing strategy [14], [15], [16]. This analysis represents a good analytic base for choosing the strategies by touristic destinations or products and the first step in the process of strategic management, done for the National Park Fruska Gora (Table 1).

Why is important to start the analysis of the touristic destination with the SWOT analysis? The reason lies in the fact that this analysis gives a clear image of the state and increases the possibilities of solving the weaknesses and threats with powers and possibilities. This kind of solving "the weak" point of the destination is implemented further through the TOWS matrix. At the beginning of the 1980s, the experts developed the TOWS matrix that analyses the same factor as the SWOT analysis, but it starts with the external factors 
or the opposite order when compared to the methodological approach of the SWOT analysis [17].

Table 1. The SWOT analysis of the NP "Fruska Gora"

\begin{tabular}{|c|c|}
\hline Strengths & Weaknesses \\
\hline $\begin{array}{l}\text { - Good touristic-geographic position and the } \\
\text { position in relation to emissive areas }\end{array}$ & $\begin{array}{l}\text { - The absence of clear vision by management } \\
\text { and state about touristic activation of National } \\
\text { park }\end{array}$ \\
\hline $\begin{array}{l}\text { - Good microlocational position and accessibility } \\
\text { of most attractive locations }\end{array}$ & $\begin{array}{l}\text { - The insufficient quality of touristic products } \\
\text { and programms }\end{array}$ \\
\hline - Ambience & $\begin{array}{l}\text {-The state of accomodation capacities in the } \\
\text { Park }\end{array}$ \\
\hline $\begin{array}{l}\text { - Favourable climate conditions during the certain } \\
\text { seasons }\end{array}$ & $\begin{array}{l}\text { - The absence of certain sport-recreative } \\
\text { contents }\end{array}$ \\
\hline- The richness of plant and animal world & - The unusage of space \\
\hline - Healing waters & - Weak touristic equipment \\
\hline - Lake accumulations & $\begin{array}{l}\text { - Non-existence of touristic agency in the } \\
\text { National Park }\end{array}$ \\
\hline $\begin{array}{l}\text { - The richness of cultural-historical monuments on } \\
\text { the park's edge }\end{array}$ & - Weak marketing activity \\
\hline \multicolumn{2}{|l|}{ - The vineyard region } \\
\hline Oportunities & Threats \\
\hline $\begin{array}{l}\text { - Wide contractive zone with the largest cities in } \\
\text { Vojvodina }\end{array}$ & - Higher urbanisation of the mountain \\
\hline - Bigger urbanisation in cities & $\begin{array}{l}\text { - Further degradation by industry and other } \\
\text { factors }\end{array}$ \\
\hline $\begin{array}{l}\text { - Very attractive villages surrounding the } \\
\text { National Park }\end{array}$ & $\begin{array}{l}\text { - Rudeness in behaviour of tourists within } \\
\text { protected national goods }\end{array}$ \\
\hline - Incorporation in the touristic fortune & - Low purchasing power of the citizens \\
\hline $\begin{array}{l}- \text { Greater touristic significance of the Danube } \\
\text { river in the european proportions }\end{array}$ & $\begin{array}{l}\text { - The increase in number of object in } \\
\text { surroundings withe the similar offer }\end{array}$ \\
\hline
\end{tabular}

The source: Created by the author and based on the interview with the management of the National park Fruska Gora, 2019.

The TOWS matrix is a tool created to match the outside opportunities and threats and internal strengths and weaknesses [12]. The TOWS matrix is in most cases presented in the form of table so that it creates four strategies, based on matching the combinations of weaknesses, threats, opportunities and strengths. Those are: WT, WO, ST and SO strategies.

The goal of the WT strategy is to minimise both weaknesses (W) and threats (T). The touristic destination that at the same time is faced with outer threats and inner weaknesses has only goal - survival. The destination solves this position with hope in the decrease of outer strengths and ending the business processes which considered as "weak".

The goal of the WO strategy is to minimise the weaknesses (W) and maximise the opportunities (O). Every touristic destination can recognise the chances in its surrounding, but it can't allow itself to have the inner weaknesses that could prevent it from answering on the opportunities from the outer surrounding.

The goal of the ST strategy is to maximise the strengths (S) that in this form can successfully "cope" with the outer threats (T) and minimise them.

The goal of the SO strategy is to maximise both strengths $(\mathrm{S})$ and opportunities $(\mathrm{O})$. This position is the main goal and wish of every destination's management. 
Table 2. The TOWS matrix of the NP "Fruska Gora"

\begin{tabular}{|c|c|c|}
\hline & $\begin{array}{l}\text { Oportunities from the } \\
\text { surrounding } \\
\text { - } \quad \text { Wide contractive zone with the } \\
\text { largest cities in Vojvodina, } \\
\text { - } \quad \text { Bigger urbanisation in cities, } \\
\text { - Very attractive villages } \\
\text { surrounding the National Park, } \\
\text { - Incorporation in the touristic } \\
\text { fortune, } \\
\text { Greater touristic significance of } \\
\text { the Danube river in european } \\
\text { proportions }\end{array}$ & $\begin{array}{l}\text { Threats from the } \\
\text { surrounding } \\
\text { - } \quad \begin{array}{l}\text { Higher urbanisation of the } \\
\text { mountain, }\end{array} \\
\text { - } \quad \begin{array}{l}\text { Further degradation by } \\
\text { industry and other factors, }\end{array} \\
\text { - } \begin{array}{l}\text { Rudeness in behaviour of } \\
\text { tourists within protected } \\
\text { national goods, }\end{array} \\
\text { - Low purchasing power of the } \\
\text { citizens, } \\
\text { The increase in number of } \\
\text { object in surroundings withe } \\
\text { the similar offer }\end{array}$ \\
\hline $\begin{array}{l}\quad \text { Strenghts } \\
\text { - } \quad \begin{array}{l}\text { Good touristic-geographic } \\
\text { position and the position in } \\
\text { relation to emissive areas, }\end{array} \\
\text { - } \quad \begin{array}{l}\text { Good microlocational position } \\
\text { and accessibility of most } \\
\text { attractive locations, }\end{array} \\
\text { - Ambience, } \\
\text { - Favourable climate conditions } \\
\text { during the certain seasons, } \\
\text { - The richness of plant and animal } \\
\text { world, } \\
\text { - } \quad \text { Mineral waters, } \\
\text { - Take accumulations, } \\
\text { The richness of cultural- } \\
\text { historical monuments on the } \\
\text { park's edge, } \\
\text { The vineyard region }\end{array}$ & $\begin{array}{l}\text { SO Strategy } \\
\text { - } \quad \text { Introducing the new product } \\
\text { on current markets or current } \\
\text { products to the new markets } \\
\text { Attracting new touristic } \\
\text { groups to new touristic } \\
\text { programs } \\
\text { Strengthening competitive } \\
\text { advantage by emphasizing all } \\
\text { the attractive places in } \\
\text { Fruska Gora }\end{array}$ & $\begin{array}{l}\text { ST Strategy } \\
\text { - } \quad \text { The use of current economical } \\
\text { situation to activate those touristic } \\
\text { destinations closest to the tourist } \\
\text { - } \quad \text { Researching the market to follow } \\
\text { the trends and consumer's demands } \\
\text { for directing own possibilities for } \\
\text { growth and development } \\
\text { and.cognition about new } \\
\text { necessary product and services } \\
\text { Co-operation between all the } \\
\text { touristic agencies of municipalities } \\
\text { on the territory of the National } \\
\text { park } \\
\text { Increasing the consciousness about } \\
\text { conservation of the environment in } \\
\text { the National park }\end{array}$ \\
\hline $\begin{array}{l}\text { Weaknesses } \\
\text { - } \quad \text { The absence of clear vision by } \\
\text { management and state about } \\
\text { touristic activation of the } \\
\text { National park } \\
\text { The insufficient quality of } \\
\text { touristic products and } \\
\text { programms } \\
\text { The state of accomodation } \\
\text { capacities in the Park } \\
\text { - The absence of certain sport- } \\
\text { recreative contents } \\
\text { - Unusage of space } \\
\text { - Weak touristic equipment } \\
\text { Non-existence of touristic } \\
\text { - Wency in the National Park } \\
\text { Weak marketing activity }\end{array}$ & $\begin{array}{l}\text { WO Strategy } \\
\text { - Creating the destinational } \\
\text { management for efficient } \\
\text { directing of space } \\
\text { - The new access to sale - a } \\
\text { modern marketing plan, } \\
\text { acuteness and efficiency } \\
\text { A touristic valorisation of the } \\
\text { most attractive locations on the } \\
\text { mountain and adaptedness to the } \\
\text { region's touristic offer }\end{array}$ & $\begin{array}{l}\text { WT Strategy } \\
\text { - } \quad \text { Maximal use of existing } \\
\text { resources on the most } \\
\text { efficient way } \\
\text { - } \\
\text { Adapting to existing } \\
\text { economical situation when } \\
\text { creating touristic programs } \\
\text { - Cutting the expenses in all the } \\
\text { accommodation object on the } \\
\text { mountain, but preserving the } \\
\text { quality } \\
\text { Efficient application of the } \\
\text { Law of National Parks }\end{array}$ \\
\hline
\end{tabular}

Source: Created by the author, and based on the interview

with the management of the National park Fruska Gora, 2019.

From the TOWS matrix and based on the clear display of weaknesses, strengths, threats and opportunities all the possible strategies in NP Fruska Gora are enlisted (Table 2). A destination, depending on its position chooses the strategy that is the most adequate at that moment, taking into consideration the biggest influence on the positioning on the market. With both approaches, the SWOT analysis and the TOWS matrix we identify the critical factors of success or failure. Because of that, this technique and its methodological frame got a wide usage in practicing of strategic analysis and choosing the strategic option 
for organisations, or companies as well as for the touristic product and destinations [8]. Of course, we have to emphasize that the pre-condition of all these analyses is the existence of management of the touristic destination Fruska Gora with a clear vision about the touristic activation of this place.

\section{Choosing and implementing the strategy}

The formulation of strategy involves a systematic approach that is in accordance with treating the touristic destination as a complex system. The criteria for the successfulness of strategies is their contribution in the creation of a unique destination's competence in carrying out the business activity; that is a precondition for competitive advantage [18]. To define the strategy, it is necessary to determine different ways or different strategic options (its generating, rating and choice) for realisation of the mission and the goals of destination. Based on previously done SWOT analysis and TOWS matrix, the most adequate one would be the implementation of growth strategy, the strategies of market and product development.

Because every development concept must come to the needs and wishes of users, it is necessary to analyse of the potential markets to come to the potential touristic demand for the touristic offer in Fruska Gora. During the analysis of the touristic demand for the touristic products of Fruska Gora, it is necessary to analyse three basic components:

- Tourist-geographical position in relation to places tourists come from and other touristic destinations is very favourable and it is one of the most significant stimulative factors of tourism development.

- Traffic position of Fruska Gora that is on the first site very favourable and stimulates touristic visits - because of the accessibility (a number of roads from all directions) and a small distance from the emissive areas. However, the position is also a restrictive factor because the roads are in a bad shape and this fact discourages trips and extends the trip time. The important factor is a shortage of information boards and signposts which affects the unsafety of movement through space.

- Current country-political and social situation as a more complex factor.

- However, with the third component, this kind of momentum can be good for the development of tourism in Fruska Gora from these reasons [19]:

- Complex space communications with further regions and world, direct potential tourist to the closest attractive destinations,

- Narrowed possibilities for satisfying expressive touristic needs of citizens of Vojvodina and Belgrade (that are in the closest contractive zone), direct tourist to the closest touristic destinations that kept or developed basic elements of a touristically attractive offer

- Economical and social situation of the citizens form the contractive zone of Fruska Gora - in general is not very favourable in terms of development of those forms of tourism that demand more investment and bring the high price for space usage, but on the other hand, low life standard directs the potential tourists to choose closer and cheaper programs that have favourable conditions on the observed space

The touristic demand is measured as a favourable component of the touristic development; as a side of touristic market to which elastic and well-organised offer must be turned to.

According to the characteristics of potential tourists, in Fruska Gora you can expect these segments of demand [20]:

- school kids - organised with schools or other organizations 
- youth - students organised; youth organizations

- mountaineers, scouts, rangers, people on holidays, ecologists,

- young researchers, musical or literary youth and other youth organizations, nongovernmental or similar youth organizations,

- sportsmen - organised with their clubs, sport schools and centres,

- grown-ups and mixed groups,

- organised groups - mountaineers, recreates, expert groups,

- non-organised groups.

The necessity of applying the generic strategies also represents the imperative of successful positioning of the NP "Fruska Gora" on the touristic market. It is considered that the number and the structure of the accommodation objects are enough for providing service for tourists (Table 3), but their equipment, organisation and functioning are not satisfying level. In the past few decades, there hasn't been a significant change in the quantitative and qualitative characteristics of the accommodation capacities in Fruska Gora. Significant changes are happening during the past few years when the first object of I category hotel "Premier aqua" in Vrdnik was opened, than tourist village "Vrdnicka kula" and thermal spa resort "Fruske Terme" and this represents a successful step toward improvement and development of the touristic product of this destination. In this way, demanding market segments can be satisfied and it shows that the hotel's specialization and the development of wellness tourism is another form of tourism which can contribute to the development of this mountain.

Table 3. The accommodation capacities in Fruska Gora (new data)

\begin{tabular}{|c|c|c|}
\hline The type of accommodation & $\begin{array}{c}\text { The number of } \\
\text { objects }\end{array}$ & The number of beds \\
\hline Hotels & 4 & 929 \\
\hline Tourist village & 1 & 96 \\
\hline Motels & 3 & 202 \\
\hline Resorts & 4 & 590 \\
\hline Mountain lodges & 12 & 321 \\
\hline Total & $\mathbf{2 4}$ & $\mathbf{2 1 3 8}$ \\
\hline
\end{tabular}

Source: [21]

The strategy of product differentiation is implemented on this example (the differentiation according to the quality) and in this way the necessity of strategic directing and thinking in tourism is pointed out.

\section{CONCLUSION}

Modern trends and predictions about the character of changes especially in the surrounding, condition that the appliance of strategic directing concept will be necessary with the goal to secure the basis for efficiency and effectiveness of activities in Fruska Gora, its growth and development. The biggest problem in development of tourism in the National park Fruska Gora so far was the fact that the bearers of tourism development were not clearly defined; the fact that the users of that space do not bear the consequences of insufficient or inadequate usage of space and the fact that the chosen development programs were not implemented. The most important thing is that there is no strategic decision whether or not tourism is wanted in Fruska Gora because the modern touristic market demand concrete development program and the implementation of growth 
strategies as well as the generic strategies that offer attractive, specific and rare products to curios and selective tourists.

\section{REFERENCES}

[1] Vukosav, S., Prilagođavanje je hotelskog proizvoda Vojvodine savremenim tendencijama u turizmu, doktorska teza u rukopisu, PMF, Departman za geografiju, turizam i hotelijerstvo, Novi Sad, (2010).

[2] Stojanović, V. Primena koncepta održivog razvoja u specijalnim rezervatima prirode Vojvodine, Doktorska disertacija (u rukopisu), Prirodno-matematički fakultet, Departman za geografiju turizam i hotelijerstvo, Novi Sad, (2004).

[3] Tomić, P., i drugi, Zaštićena prirodna dobra i ekoturizam Vojvodine, Prirodno-matematički fakultet, Departman za geografiju turizam i hotelijerstvo, Novi Sad, (2004).

[4] Feifan, X. P. Developing industrial heritage tourism: A case study of the proposed jeep museum in Toledo, Ohio, Tourism Management, vol. 27(1), pp. 1321-1330, (2006).

[5] Okumus, F., Köseoglu,M.A., Morvillo, A., Altinay, L., Chathoth, P. Scientific progress on strategic management in hospitality and tourism:a state-of-the-art, Tourism Review, vol. 72 (3), pp. 261-273, (2017).

[6] Okumus, F., Altinay, L., Chathoth, P. Strategic Management for Hospitality and Tourism, Elsevier, Oxford, (2010).

[7] Dobre, R., Menadžment turističke destinacije, Visoka škola za turistički menadžment, Sibenik, (2004).

[8] Čerović, S., Strategijski menadžment u turizmu, Univerzitet Singidunum, FTHM, Beograd, (2009).

[9] Pavlović, L., Model kontinuiranog poboljšanja poslovnih procesa u turizmu primjenom kontrolinga, magistarska teza u rukopisu, Sveučilište u Zagrebu, Fakultet organizacije informatike Varaždin, (2006).

[10] Bakić, O., Marketing u turizmu, Fakultet za uslužni biznis, Sremska Kamenica (Novi Sad), (2008).

[11] Weaver, D., Lawton, L., Tourism Management, John Wiley and Sons, Australia, (2002).

[12] Vukosav, S., Strategijski menadžment ugostiteljsko - turističkih preduzeća, Prirodnomatematički fakultet, Departman za geografiju, turizam i hotelijerstvo, Novi Sad, (2016).

[13] Milisavljević, M. Strategijski menadžment: analiza, izbor i promena, Centar za izdavačku delatnost Ekonomskog fakulteta, Beograd, (2012).

[14] Meredith, D., Fred, D., Forest, D., The quantitative strategic planning matrix: a new marketing tool, Journal of Strategic Marketing, 25, pp. 1-12, (2016).

[15] Helms, M. M., Nixon, J. Exploring SWOT analysis - where are we now?: A review of academic research from the last decade, Journal of Strategy and Management, vol. 3(3), pp. 215251, (2010).

[16] Panagiotou, G. Bringing SWOT into focus, Business Strategy Review, vol. 14(1), pp. 8-10, (2003).

[17] Wechrich, H., The TOWS Matrix - A Toll for Situational Analysis, Long Range Planing, No.4/1993., str.60-64.

[18] Popesku, J., Menadžment turističke destinacije, Univerzitet Singidunum, Beograd, (2011).

[19] Obradović, S., Turistička valorizacija Nacionalnog parka „Fruška gora” i održivi razvoj, magistarska teza u rukopisu, PMF, Departman za geografiju, turizam i hotelijerstvo, Novi Sad, (2005).

[20] Tomka, D., Tekst za Prostorni plan područja posebne namene Fruške gore do 2020. godine, Novi Sad, (2003).

[21] Data obtained from the management of JP „Fruska Gora National Park“, 2019. 